\title{
Preparation of CO Gas Sensor from ZnO Material Synthesized via Thermo-Oxidation Process
}

\author{
Diah Susanti ${ }^{1}$, Endah Lutfiana ${ }^{1}$, Haniffudin Nurdiansah ${ }^{1}$, Hariyati Purwaningsih ${ }^{1}$, Lukman Noerochiem $^{1} \&$ \\ George Endri Kusuma ${ }^{2}$ \\ ${ }^{1}$ Department of Materials and Metallurgical Engineering, Sepuluh Nopember Institute of Technology, Indonesia \\ ${ }^{2}$ Department of Mechanical Engineering, Surabaya State Ship-building Polytechnic, Indonesia \\ Correspondence: Diah Susanti, Department of Materials and Metallurgical Engineering, Sepuluh Nopember \\ Institute of Technology, Surabaya, 60111, Indonesia. E-mail: santiche@mat-eng.its.ac.id
}

Received: May 4, 2015

Accepted: June 5, 2015

Online Published: June 30, 2015

doi:10.5539/mas.v9n7p127

URL: http://dx.doi.org/10.5539/mas.v9n7p127

\begin{abstract}
Carbon monoxide (CO) is poisonous to human because of its nature which is capable to bind to the haemoglobin in blood stronger than oxygen, so that causing toxication and even death. Therefore a sensor to early detect the presence of $\mathrm{CO}$ gas is necessary. $\mathrm{ZnO}$ is one of semiconductor materials which widely applied as a sensor material. However, $\mathrm{ZnO}$ is rarely reported as a $\mathrm{CO}$ gas sensor material. In this study, $\mathrm{ZnO}$ as a sensor material has been synthesized by thermo-oxidation of $\mathrm{Zn}$ powder at oxidation temperature variations of 800,850 and 900 ${ }^{\circ} \mathrm{C}$. The synthesized $\mathrm{ZnO}$ was crushed and compacted to form pellet for sensor chip. The $\mathrm{ZnO}$ pellets were then sintered at $500{ }^{\circ} \mathrm{C}$. The material structures were examined using Scanning Electron Microscope (SEM), X-Ray Diffractometer (XRD), and Brunauer-Emmet-Teller (BET) analysis. The sensitivity test towards CO gas was conducted with the variations in sensing operating temperatures of $30,50,100{ }^{\circ} \mathrm{C}$ and variation of $\mathrm{CO}$ gas input concentration of $10 \mathrm{ppm}, 50 \mathrm{ppm}, 100 \mathrm{ppm}, 250 \mathrm{ppm}$, and $500 \mathrm{ppm}$. The sensitivity test results showed that the sensitivity towards $\mathrm{CO}$ gas decreased as the oxidation temperature increased. In addition the sensitivity increased along with the increasing of the sensing operating temperature and $\mathrm{CO}$ gas input concentration. Hence, the highest sensitivity value was obtained from $\mathrm{ZnO}$ material synthesized at $800^{\circ} \mathrm{C}$ due to the highest active surface area of $69.4 \mathrm{~m}^{2} \mathrm{~g}^{-1}$ with $\mathrm{CO}$ concentration of $500 \mathrm{ppm}$ and sensor operating temperature of $100^{\circ} \mathrm{C}$.
\end{abstract}

Keywords: $\mathrm{ZnO}$, thermo-oxidation, $\mathrm{CO}$ gas, sensitivity

\section{Introduction}

Carbon monoxide (CO) is a poisonous gas having characteristics of colorless and odorless. It occupies the earth atmosphere in long period and is unable to dissolve in water. This gas is produced from incomplete combustion of carbon-based materials such as wood, coal, oil fuel and other organic substances (Kao and Nanagas, 2004). It is also a side product of living-organism metabolisms. The important biological characteristic of CO is its ability to bind to hemoglobin, the red blood cell pigment, which carried oxygen throughout the body. These properties result in the formation of carboxy-hemoglobin ( $\mathrm{HbCO}$ ) which is 200 times more stable than oxy-hemoglobin $\left(\mathrm{HbO}_{2}\right)$. The relatively slow decomposition of $\mathrm{HbCO}$ can impede the work of the pigment molecules in the function of cells in carrying oxygen throughout the body. These conditions could cause poisoning even death. Due to the nature of CO gas that cannot be perceived by human senses and the hazard of CO gas to the human body, therefore, a sensor to early detect the presence of $\mathrm{CO}$ gas in the air is very necessary.

Research on metal oxide materials gradually spreads because the applications of metal oxide materials are quite a lot including as toxic gas sensors, optical and modulation optoelectrochromic, photocatalyst, hydrophilic surface design, and catalyst. The metal oxides frequently used for sensor materials are $\mathrm{TiO}_{2}, \mathrm{SnO}_{2}, \mathrm{ZnO}$, and $\mathrm{WO}_{3}$ (Wang, et al., 2003). As one of the most prominent materials for gas sensors, $\mathrm{ZnO}$ has shown good response towards pollutant gas such as $\mathrm{H}_{2} \mathrm{~S}$, NOx, and benzene (Calestani et al., 2010) and other gases such as $\mathrm{H}_{2}$, CO, ethanol and acetone (Moon et al., 2009).

$\mathrm{ZnO}$ has been successfully synthesized by various techniques such as hydrothermal (Peng and Huo, 2009), vapor-liquid-solid (Tsueh et al., 2007), sol-gel (Tseng, et al., 2012), spray pyrolysis (Widiyastuti et al., 2012) and physical vapor deposition (PVD) (Jimenes-Cadena et al., 2010). Those methods are quite complicated and 
expensive. One method that is simple and inexpensive is direct thermo-oxidation of $\mathrm{Zn}$ powder into $\mathrm{ZnO}$ (Khanlary et al., 2012).

$\mathrm{Zn}$ is one of some metals having low melting temperature of $420^{\circ} \mathrm{C}$ and low boiling temperature of $907{ }^{\circ} \mathrm{C}$ (Gaskell, D.R., 1973). The free energy formation of $\mathrm{ZnO}$ at $25^{\circ} \mathrm{C}$ is $-79.19 \mathrm{kcal}$ mole ${ }^{-1}$ (Perry et al., 1997) hence thermodynamically the oxidation process of $\mathrm{Zn}$ into $\mathrm{ZnO}$ occurs spontaneously at room temperature. However, kinetically the process is relatively slow. The Gibbs' free energy of $\mathrm{Zn}$ oxidation into $\mathrm{ZnO}$ based on this below reaction:

is

$$
\mathrm{Zn}_{(g)}+1 / 2 \mathrm{O}_{2(g)} \rightarrow \mathrm{ZnO}_{(s)}
$$

$$
\Delta G^{\circ}=-115,420-10.35 T \log T+82.38 T(\mathrm{cal})
$$

in temperatures ranging from $897^{\circ} \mathrm{C}$ to $1727^{\circ} \mathrm{C}$ in which the $\mathrm{Zn}$ is in the gaseous state (Gaskell, D.R., 1973). In those temperature ranges, the oxidation process also occurs spontaneously since the Gibbs' free energy is always negative. The oxidation process of $\mathrm{Zn}$ into $\mathrm{ZnO}$ is an endothermic process. For endothermic process, increasing the temperature will cause the equilibrium to shift to the right, meaning that the reaction will proceed almost completely in relatively short time.

Therefore, in this research, $\mathrm{ZnO}$ was synthesized from $\mathrm{Zn}$ powder which was directly heated under atmospheric air to become $\mathrm{ZnO}$ at temperatures nearly close to the boiling temperature of $\mathrm{Zn}$ to let the oxidation process to complete fast. The $\mathrm{ZnO}$ powder was then compacted into pellet and applied as a sensor chip for $\mathrm{CO}$ gas. The correlations between $\mathrm{ZnO}$ structure and sensitivity towards $\mathrm{CO}$ gas were analyzed and reported.

\section{Method}

Synthesis of zinc oxide $(\mathrm{ZnO})$ was conducted by heating 2 grams of $\mathrm{Zn}$ powder (Merck, size $<45 \mu \mathrm{m}$ ) in a muffle furnace under atmospheric air at various temperatures of 800,850 , and $900{ }^{\circ} \mathrm{C}$ for 40 minutes. The resulted $\mathrm{ZnO}$ was crushed and sieved to form powder with sizes less than $80 \mu \mathrm{m}$. The powder was then pelletized using hydraulic compaction machine with a pressure of 200 bar. The pellet had dimensions of $14 \mathrm{~mm}$ in diameter and $3 \mathrm{~mm}$ in thickness. To enhance the bonding of $\mathrm{ZnO}$, the pellets were sintered at $500{ }^{\circ} \mathrm{C}$ for 1 hour. The opposite edges of the $\mathrm{ZnO}$ pellet were sputtered by $\mathrm{Pd} / \mathrm{Au}$ alloy metal target for 30 minutes to form electrodes and electrical connections.

X-ray powder diffaction patterns were obtained using a Philips XRD Analytical for $\mathrm{ZnO}$ samples before and after sensitivity test. The tests were performed using X-ray $\mathrm{Cu} \mathrm{K \alpha}$ source with wavelength of $1.54056 \AA$ and angle range of $10-90^{\circ}$. Scanning Electron Microscope (SEM FEI S-50) was used to observe the morphology of $\mathrm{ZnO}$ samples after thermo-oxidation, after sieving process, after sintering process and after sensitivity tests. BET (Quantrachrome AsiQwin) was conducted to determine the active surface of the $\mathrm{ZnO}$ powder using nitrogen gas.

The sensitivity test towards $\mathrm{CO}$ gas was performed inside a stainless-steel chamber equipped with a thermo-controller, electrical connections to potentiostat instrument (Versastat 4.0 by Par Ametek) and channels to a vacuum pump and gas sources. The sample was placed in the middle of a ceramic disk heater inside the chamber. The chamber was initially pumped to vacuum and the sample was set at room temperature $\left(30^{\circ} \mathrm{C}\right)$. The air was flown inside the chamber with a volume of 20 liters (the volume of chamber). The air resistance was measured using potentiostat instrument under the potential difference of $1.5 \mathrm{~V}$. The resistance of air was denoted as $\mathrm{R}_{\mathrm{o}}(\Omega)$. The $\mathrm{CO}$ gas was then flown inside a chamber using a mass flow controller (MFC Sierra C50) so that the $\mathrm{CO}$ concentration was set at $10 \mathrm{ppm}$. The resistance under the presence of $\mathrm{CO}$ gas was measured and denoted as $\mathrm{R}_{\mathrm{g}}(\Omega)$. These steps were repetitively performed with different $\mathrm{CO}$ gas concentrations of $100 \mathrm{ppm}, 250 \mathrm{ppm}$, and $500 \mathrm{ppm}$. After completion, the operating temperatures were successively changed to $50^{\circ} \mathrm{C}$ and $100{ }^{\circ} \mathrm{C}$, each with various $\mathrm{CO}$ gas concentrations as mentioned above. The sensitivity values were calculated with the equation below (Wang et al., 2003):

$$
S=\left|R_{g}-R_{o}\right| / R_{o}
$$

Where $\mathrm{S}$ is the sensitivity of the sensor, $\mathrm{R}_{\mathrm{g}}$ is the resistance after CO gas flowing and expressed in ohms $(\Omega)$, and $\mathrm{R}_{0}$ is the resistance of air before CO gas flowing and expressed in ohms $(\Omega)$.

\section{Results and Discussion}

$\mathrm{XRD}$ results for $\mathrm{ZnO}$ powder before sensitivity test are shown in Figure 1. These results match well with the JCPDF number 790206 of $\mathrm{ZnO}$ with hexagonal structure. The XRD patterns showed the three dominant crystal plane orientations $(101)$ at $2 \theta=36.25^{\circ},(100)$ at $31.77^{\circ}$, and $(002)$ at $34.42^{\circ}$. As synthesis temperature increased, the XRD peaks became sharper and the intensities also became higher. Hence the samples had better crystalline quality as the synthesis temperature increased (Khanlary, et al., 2012). 


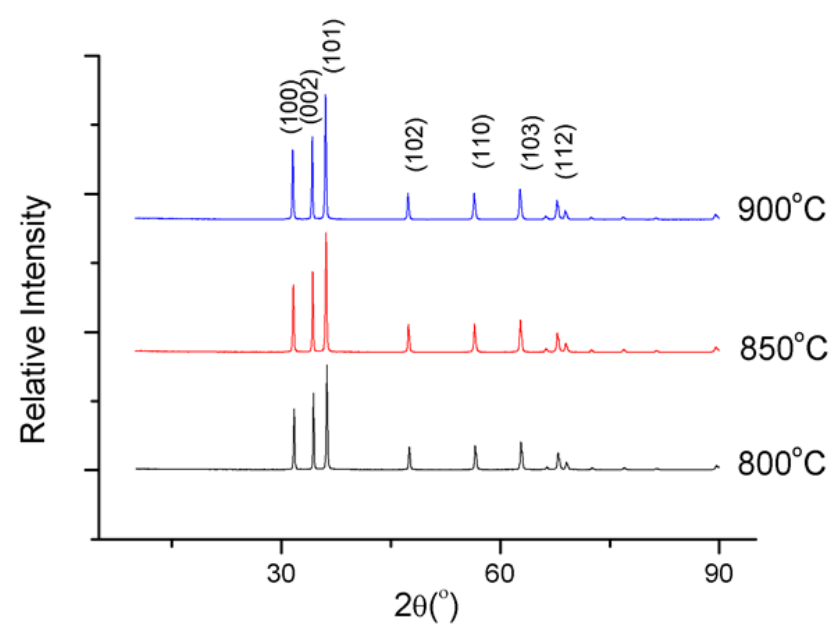

Figure 1. Comparison of the diffraction patterns of $\mathrm{ZnO}$ pellets synthesized at $800{ }^{\circ} \mathrm{C}, 850{ }^{\circ} \mathrm{C}$, and $900{ }^{\circ} \mathrm{C}$ before sensitivity test towards $\mathrm{CO}$ gas

Table 1. Comparison of the crystalline size with synthesis variation temperature before and after sensitivity test towards $\mathrm{CO}$ gas

\begin{tabular}{ccc}
\hline Synthesis Temperature $\left({ }^{\circ} \mathrm{C}\right)$ & $\begin{array}{c}\mathrm{D}(\AA) \\
\text { before sensitivity test }\end{array}$ & $\begin{array}{c}\mathrm{D}(\AA) \\
\text { after sensitivity test }\end{array}$ \\
\hline 800 & 683.25 & 585.84 \\
850 & 585.45 & 585.63 \\
900 & 585.34 & 585.65 \\
\hline
\end{tabular}

$\mathrm{XRD}$ characterizations were also conducted to $\mathrm{ZnO}$ pellets after sensitivity test towards $\mathrm{CO}$ gas as shown in Figure 2. The XRD patterns were similar to those in Figure 1. Hence $\mathrm{CO}$ gas and operating temperature variations during sensitivity tests did not contribute to the structure changes of $\mathrm{ZnO}$ sensor material. The crystalline sizes of the $\mathrm{ZnO}$ pellets before and after sensitivity tests are listed in Table 1 based on Scherrer's formula (Cullity and Stock, 2001, pp 170). The crystalline sizes before and after sensitivity test were almost similar, except the sample synthesized at $800{ }^{\circ} \mathrm{C}$, the crystalline size became smaller after the sensitivity test, which perhaps caused by the operating temperatures and mechanical treatments during sensitivity measurement, as we have encountered in our previous experiment (Susanti, et al., 2014(b)).

Figure 3 shows SEM images of $\mathrm{ZnO}$ synthesized at various temperatures $800{ }^{\circ} \mathrm{C}, 850{ }^{\circ} \mathrm{C}$ and $900{ }^{\circ} \mathrm{C}$ prior being crushed into powder. From the SEM images, the sample synthesized at $800^{\circ} \mathrm{C}$ has more pores than the others. A material with larger porosity will certainly have a greater surface area. As shown in Table 2, the sample synthesized at $800{ }^{\circ} \mathrm{C}$ has the largest active surface area based on BET measurements. While those synthesized at $850{ }^{\circ} \mathrm{C}$ and $900{ }^{\circ} \mathrm{C}$ have almost similar active surface area. As synthesis temperature increased, material will have larger particle size, hence less pores (Dutta and Bose, 2012).

Table 2. Surface area of $\mathrm{ZnO}$ powder from BET measurement

\begin{tabular}{lccc}
\hline & \multicolumn{3}{c}{ Synthesis temperature $\left({ }^{\circ} \mathrm{C}\right)$} \\
\cline { 2 - 4 } & 800 & 850 & 900 \\
\hline BET surface area $\left(\mathrm{m}^{2} \mathrm{~g}^{-1}\right)$ & 69.4 & 0.38 & 0.42 \\
\hline
\end{tabular}




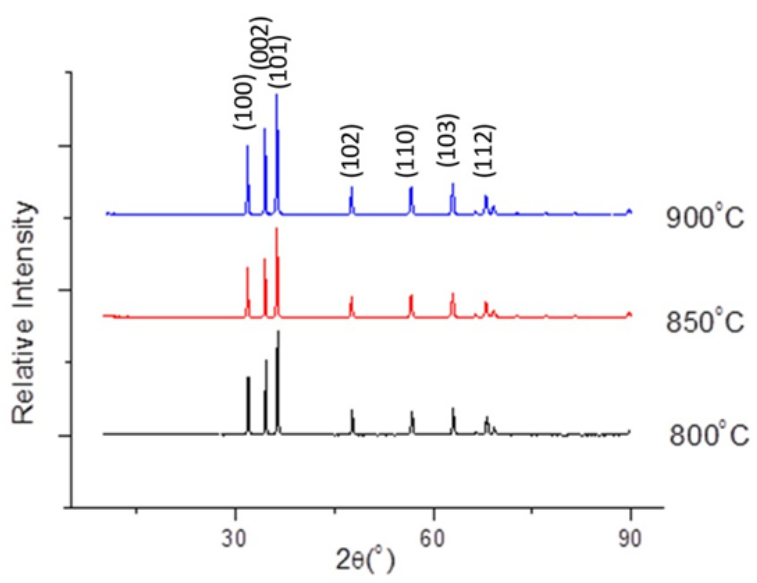

Figure 2. Comparison of the diffraction patterns of $\mathrm{ZnO}$ pellets synthesized at $800{ }^{\circ} \mathrm{C}, 850{ }^{\circ} \mathrm{C}$ and $900{ }^{\circ} \mathrm{C}$ after exposure to $\mathrm{CO}$ gas

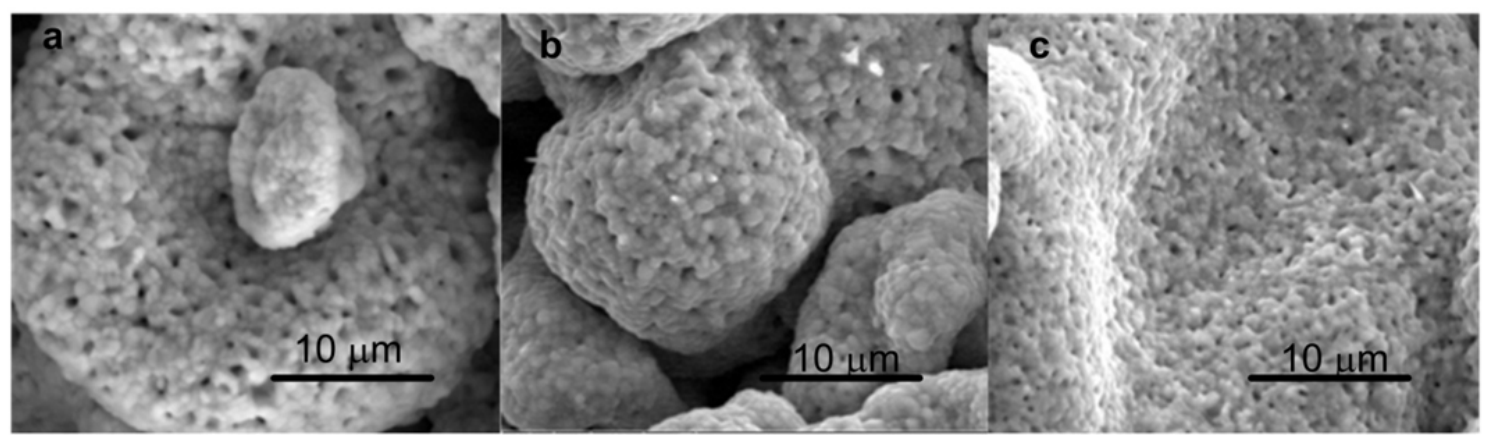

Figure 3. Bright field SEM images for $\mathrm{ZnO}$ synthesized at a) $800^{\circ} \mathrm{C}$, b) $850{ }^{\circ} \mathrm{C}$ and c) $900{ }^{\circ} \mathrm{C}$ before being crushed into powder

Comparing Figure 4 with Figure 5, there is no significant difference between the material morphologies before and after $\mathrm{CO}$ gas exposure. These results were in-line with XRD measurements which showed no significant difference in the particle sizes before and after sensitivity measurements. In our previous experiment on $\mathrm{WO}_{3}$ semiconductor material as $\mathrm{CO}$ gas sensor, we also found that the structure and morphology of $\mathrm{WO}_{3}$ did not change much after $\mathrm{CO}$ gas exposure (Susanti, et al., 2014(b)). Hence, $\mathrm{ZnO}$ is a good and suitable semiconductor material for $\mathrm{CO}$ gas sensor material, since it is stable and inert towards $\mathrm{CO}$ gas.

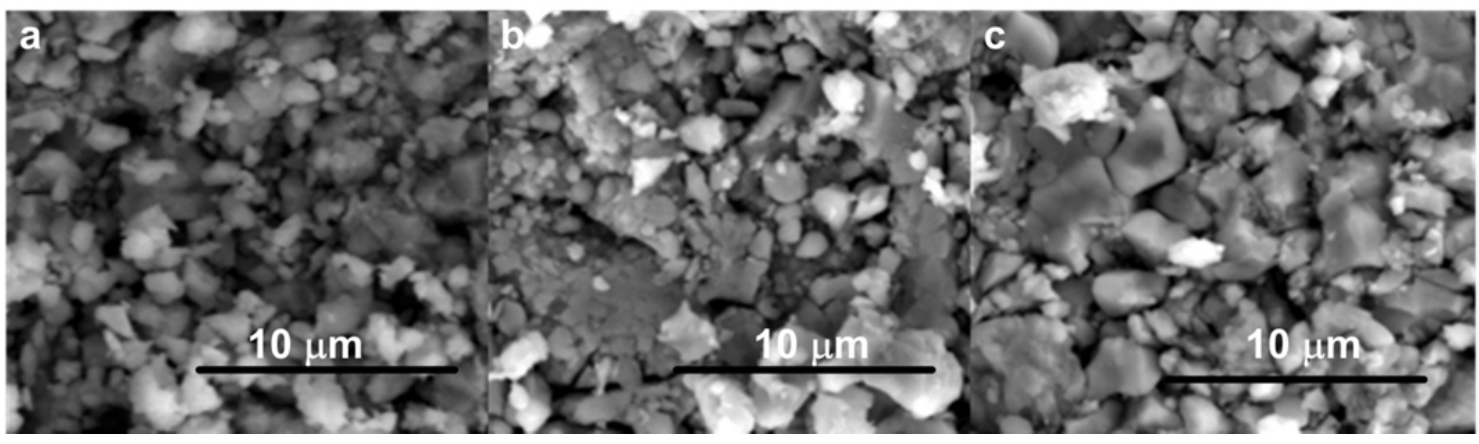

Figure 4. Bright field SEM images of $\mathrm{ZnO}$ pellets for sample with various synthesis temperatures a) $800{ }^{\circ} \mathrm{C}, \mathrm{b}$ ) $850{ }^{\circ} \mathrm{C}$ and c) $900{ }^{\circ} \mathrm{C}$ before $\mathrm{CO}$ gas exposure 


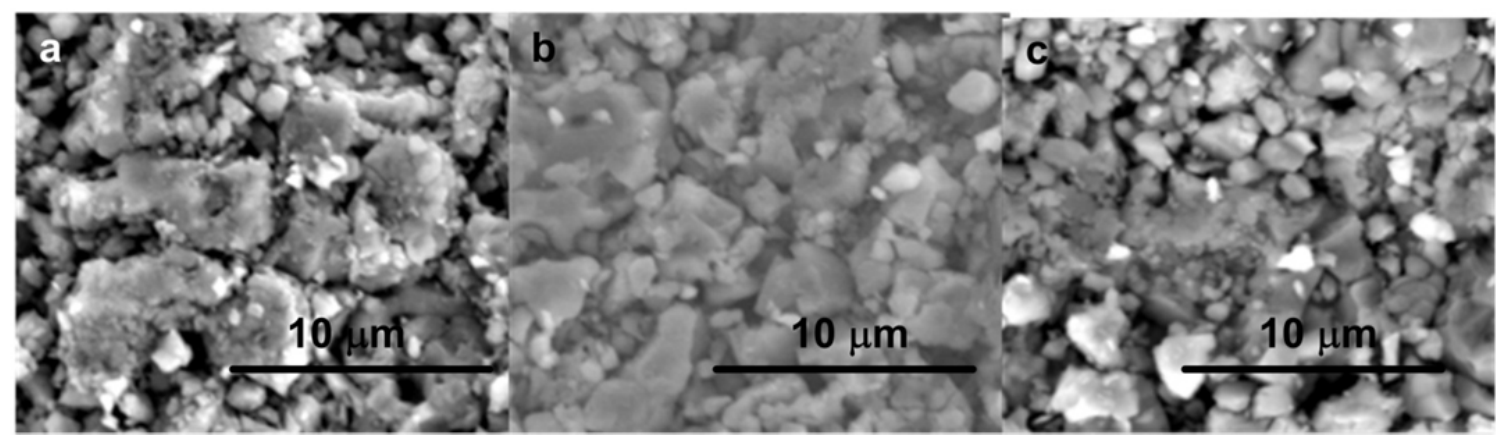

Figur 5. Bright field SEM images of $\mathrm{ZnO}$ pellets for sample with various synthesis temperatures a) $800{ }^{\circ} \mathrm{C}$, b) $850{ }^{\circ} \mathrm{C}$ and c) $900^{\circ} \mathrm{C}$ after $\mathrm{CO}$ gas exposure

Figures 4 and 5 show the bright field SEM images of $\mathrm{ZnO}$ pellets, before and after sensitivity measurements towards $\mathrm{CO}$ gas respectively. $\mathrm{ZnO}$ material in the three samples had irregular shapes. Some of them formed clusters in bigger sizes as the influence of compaction and sintering process. The sample synthesized at $800{ }^{\circ} \mathrm{C}$ has particle sizes ranging from $0.83-1.77 \mu \mathrm{m}$, while those synthesized at $850{ }^{\circ} \mathrm{C}$ and $900{ }^{\circ} \mathrm{C}$ have particle sizes ranging from $1.16-5.81 \mu \mathrm{m}$ and $1.48-6.22 \mu \mathrm{m}$, respectively. The synthesis temperature certainly has great effect on the material structure.

The results of sensitivity test of the $\mathrm{ZnO}$-based $\mathrm{CO}$ gas sensor are displayed in Figure 6. From Figure 6, the sample synthesized at $800{ }^{\circ} \mathrm{C}$ always has the highest sensitivity, followed by the sample synthesized at $850{ }^{\circ} \mathrm{C}$ and $900{ }^{\circ} \mathrm{C}$. Tamaki, et.al reported that the grain size strongly influenced the sensitivity of $\mathrm{WO}_{3}$ towards nitrogen oxides. The sensitivity of the sensor increased as the grain size decreased. Hidayat, et.al also reported that the adsorption performance of tungsten oxide towards methylene blue is dependent on particle size. The interaction between surface atoms of tungsten oxide and methylene blue molecules was increased with reduction in tungsten oxide particle size. In this experiment, $\mathrm{ZnO}$ synthesized at $800{ }^{\circ} \mathrm{C}$ had the highest active surface area and the smallest particle sizes. Therefore it showed the most sensitivity towards CO gas. Larger active surface area will accommodate more $\mathrm{CO}$ gas and increase the sensitivity.

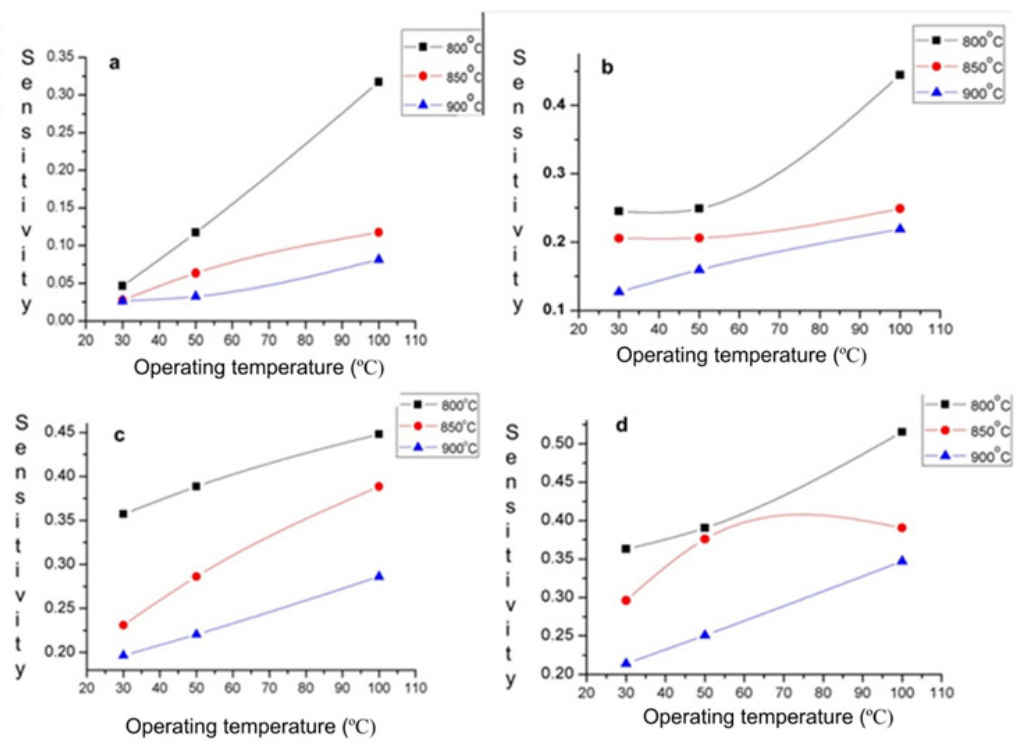

Figure 6. The sensitivity test of $\mathrm{ZnO}$-based $\mathrm{CO}$ gas sensor synthesized at various temperatures $800 \mathrm{oC}, 850 \mathrm{oC}$ and $900 \mathrm{oC}$ at different operating temperatures $30 \mathrm{oC}, 50 \mathrm{oC}$ and $100 \mathrm{oC}$ and $\mathrm{CO}$ gas concentration a) $10 \mathrm{ppm}, \mathrm{b}$ ) $100 \mathrm{ppm}, \mathrm{c}) 250 \mathrm{ppm}, \mathrm{d}) 500 \mathrm{ppm}$

Figure 6 also depicted the sensitivity dependencies to operating temperature and $\mathrm{CO}$ gas concentration. For all of the samples, the sensitivity increased as operating temperature and $\mathrm{CO}$ gas concentration increased. The sensor worked based on the chemisorbtion principle of $\mathrm{CO}$ gas onto $\mathrm{ZnO}$ surface. The oxygen molecule from the air 
would be adsorbed onto $\mathrm{ZnO}$ surface area and would bind to electrons extracted from the conduction band of $\mathrm{ZnO}$. When $\mathrm{CO}$ gas was present, the adsorbed oxygen and $\mathrm{CO}$ gas would react to form $\mathrm{CO}_{2}$ gas and release the electrons back to the conduction band of $\mathrm{ZnO}$ as shown in equation (2) and (3). The electron flows influence the electrical resistance changes of $\mathrm{ZnO}$ sensor (Hung, et al., 2010). As CO gas concentration increased, more electrons would be extracted from semiconductor material conduction band and hence the resistance along with the sensitivity would increase.

$$
\begin{array}{ll}
\text { Oxidation: } & 1 / 2 \mathrm{O}_{2}{ }^{\mathrm{g}}+\mathrm{e}^{-} \leftrightarrow \mathrm{O}^{\text {ad- }} \\
\text { Reduction: } & \mathrm{CO}+\mathrm{O}^{\text {ad- }} \leftrightarrow \mathrm{CO}_{2}{ }^{\mathrm{g}}+\mathrm{e}^{-}
\end{array}
$$

The reaction between oxygen and CO gas certainly need energy (Liu et al., 2008). Therefore at low operating temperature, the sensitivity of the sensor was also low. However at higher temperature, more oxygen and $\mathrm{CO}$ would be adsorbed onto $\mathrm{ZnO}$ surface and react to become $\mathrm{CO}_{2}$ gas, leading to the increase in sensor resistance and sensitivity (Susanti et al., 2014a).

Comparing with our previous results on $\mathrm{WO}_{3}$ for $\mathrm{CO}$ gas sensor (Susanti, et al., 2014(a) and 2014(b)), the highest sensitivity towards $\mathrm{CO}$ gas of 0.52 performed by the sample synthesized at $800{ }^{\circ} \mathrm{C}$ at $100{ }^{\circ} \mathrm{C}$ operating temperature and $500 \mathrm{ppm} \mathrm{CO}$ gas concentration was lower although it had higher active surface area than the $\mathrm{WO}_{3}$ sample performed the highest sensitivity. Therefore, it was not only the high active surface area determining the sensitivity, but also some other aspects such as the particle size, crystallite size, active surface area, oxygen vacancy, crystallinity, material electrical conductivity and interdependency among those aspects (Susanti et al., 2014(a)).

Comparing with the work reported by Hsueh, et.al (2007) on the sensitivity of ZnO deposited on top of patterned $\mathrm{Ga} / \mathrm{SiO}_{2} / \mathrm{Si}$ towards $\mathrm{CO}$ gas, our highest sensitivity was comparable. They reported the highest sensitivity to be $0.57(57 \%)$ at $320{ }^{\circ} \mathrm{C}$ operating temperature and $500 \mathrm{ppm} \mathrm{CO}$ gas concentration resulted from $\mathrm{ZnO}$ sensor material synthesized using 0.25 gram Zn. Liu, et.al (2008) reported even higher sensitivity. They reported the highest sensitivity of $\mathrm{ZnO}$ sensor material to be $0.6(60 \%)$ at $250{ }^{\circ} \mathrm{C}$ operating temperature and $70 \mathrm{ppm} \mathrm{CO}$ gas concentration.

Despite of the lower sensitivity reported in our work, $\mathrm{ZnO}$ has been proved to be a good candidate for $\mathrm{CO}$ gas sensor material.

\section{Conclusions}

$\mathrm{ZnO}$ as a material for $\mathrm{CO}$ gas sensor has been successfully synthesized via thermo-oxidation process of Zinc powder. XRD measurements confirmed the formation of $\mathrm{ZnO}$ having hexagonal structure without any other impurities. The $\mathrm{ZnO}$ sensor pellet synthesized at $800{ }^{\circ} \mathrm{C}$ performed the highest sensitivity towards $\mathrm{CO}$ gas for its largest active surface area. It was also showed that the sensitivity towards $\mathrm{CO}$ gas increased with operating temperature and $\mathrm{CO}$ gas concentration. The highest sensitivity towards $\mathrm{CO}$ gas was measured to be 0.52 performed by the sample oxidized at $800{ }^{\circ} \mathrm{C}$ at operating temperature of $100{ }^{\circ} \mathrm{C}$ and $\mathrm{CO}$ gas concentration of 500 ppm. SEM and XRD analysis have also revealed the potency of $\mathrm{ZnO}$ material for $\mathrm{CO}$ gas sensor, since there was no significant change in the morphology and structure of $\mathrm{ZnO}$ material after $\mathrm{CO}$ gas exposure. Therefore $\mathrm{ZnO}$ is a good candidate for $\mathrm{CO}$ gas sensor material since it is stable and inert towards $\mathrm{CO}$ gas.

\section{Acknowledgements}

Authors gratefully acknowledge the financial and facility supports from Ministry of Education and Culture Republic of Indonesia through International Collaboration Research Grant 2014 (BOPTN funding) and Institut Teknologi Sepuluh Nopember (ITS) - Surabaya Indonesia, respectively.

\section{References}

Calestani, D., Zha, M., Mosca, R., Zappettin, A. I., Carotta M. C., Di Natale, V., \& Zanotti. L. (2010). Growth of $\mathrm{ZnO}$ tetrapods for nanostructure-based gas sensors. Sensors and Actuators B: Chemical, 144(2), $472-478$. http://dx.doi.org/10.1016/j.snb.2009.11.009

Cullity, B. D., \& Stock, S. R. (2001). Elements of X-Ray Diffraction (3rd ed.). New Jersey, USA: Prentice Hall, pp. 170.

Dutta, G., \& Bose, D. (2012). Effect of Sintering Temperature on Density, Porosity and Hardness of a Powder Metallurgy Component. International Journal of Emerging Technology and Advanced Engineering ISSN, 2250-2459.

Gaskell, D. R. (1973). Introduction to Metallurgical Thermodynamics (International Student ed.), Washington, 
D.C.: Scripta Publishing Company, Mc.Graw-Hill Kogakusha, Ltd, pp. 498, 500.

Hidayat, D., Purwanto, A., Wang, W. N., \& Okuyama, K. (2010). Preparation of size-controlled tungsten oxide nanoparticles and evaluation of their adsorption performance. Materials Research Bulletin, 45, 165-173. http://dx.doi.org/10.1016/j.materresbull.2009.09.025

Hsueh, T. J., Chen, Y. W., Chang, S. J., Wang, S. F., Hsu, C. L., Lin, Y. R., Lin, T. S., \& Chen, I. C. (2007). ZnO nanowire-based $\mathrm{CO}$ sensors prepared on patterned $\mathrm{ZnO}: \mathrm{Ga} / \mathrm{SiO}_{2} / \mathrm{Si}$ templates. Sensors and Actuators B: Chemical, 125(2), 498-503. http://dx.doi.org/10.1016/j.snb.2007.02.059

Hung, N. L., Ahn, E. S., Jung, H. C., Kim, H. J., \& Kim, D. J. (2010). Synthesis and Gas Sensing Properties of $\mathrm{ZnO}$ Nanostructures. Journal of the Korean Physical Society, 57, 1784-1788. http://dx.doi.org/10.3938/jkps.57.1784

Jimenes-Cadena, G., Comini, E., Ferroni, M., Vomiero, A., \& Sberveglieri, G. (2010). Synthesis of different ZnO Nanostructures by modified PVD process and potential use for dye sensitized solar cell. Journal of Materials Chemistry and Physics, 124(1), 694-698. http://dx.doi.org/10.1016/j.matchemphys.2010.07.035

Kao, L. W., \& Nanagas, K. A. (2004). Carbon monoxide poisoning. Emergency medicine clinics of North America, 22(4), 985-1018. http://dx.doi.org/10.1016/j.emc.2004.05.003

Khanlary, M. R., Vahedi, V., \& Reyhani, A. (2012). Synthesis and characterization of ZnO nanowires by thermal oxidation of $\mathrm{Zn}$ thin films at various temperatures. Molecules, 17(5), 5021-5029. http://dx.doi.org/10.3390/molecules17055021

Liu, C. Y., Chen, C. F., \& Leu, J. P. (2008). Fabrication and CO sensing properties of mesostructured ZnO gas sensors. Journal of The Electrochemical Society, 156(1), J16-J19. http://dx.doi.org/10.1149/1.3021044

Moon, W. T., Jun, Y. K., Kim, H. S., Kim, W. S., \& Hong, S. H. (2009). CO gas sensing properties in Pd- added ZnO sensor. Journal of Electroceramics, 23, 196-199. http://dx.doi.org/10.1007/s10832-007-9377-y

Peng, Y., \& Huo, D. (2009). Hydrothermally Grown ZnO Crystal, Proceeding of International Symposium on Chemical Engineering of New Materials (ISCENM) 2009. Harbin, People Republic China (PRC), pp. 694-699.

Perry, R. H., Green, D. W., \& Maloney, J. O. (1997). Perry's Chemical Engineers' Handbook (7th ed.). USA: Mc.Graw-Hill, pp. 2-194.

Susanti, D., Diputra, A. A. G. P., Tananta, L., Purwaningsih, H., Kusuma, G. E., Wang, C. H., Shih, S. J., \& Huang, Y. S. (2014a). $\mathrm{WO}_{3}$ nanomaterials synthesized via a sol-gel method and calcination for use as a $\mathrm{CO}$ gas sensor. Frontiers of Chemical Science and Engineering, 8(2), 179-187. http://dx.doi.org/10.1007/s11705-014-1431-0

Susanti, D., Perdana, A. S., Purwaningsih, H., Noerochim, L., \& Kusuma, G. E. (2014b). Preparation of CO Gas Sensor from $\mathrm{WO}_{3}$ Nanomaterial Synthesized via Sol-Gel Method Followed by Hydrothermal Process. AIP Conference Proceedings, 1586, 14-19.

Tamaki, J., Zhang, Z., Fujimori, K., Akiyama, M., Harada, T., Miura, N., \& Yamazoe, N. (1994), Grain-size effects in tungsten oxide-based sensor for nitrogen oxides. Journal of Electrochemical Society, 141, 2207-2210. http://dx.doi.org/10.1149/1.2055088

Tseng, Y. K, Chuang, M. H., Chen, Y. C., \& Wu, C. H. (2012). Synthesis of 1D, 2D, and 3D ZnO Polycrystalline Nanostructures Using the Sol-Gel Method. Journal of Nanotechnology, 712850, 1-8. http://dx.doi.org/10.1155/2012/712850

Wang, S. H, Tse, C. C., \& Chung, C. L. (2003). Nano-crystalline tungsten oxide $\mathrm{NO}_{2}$ sensor. Sensors and Actuators B: Chemical, 94, 343-351. http://dx.doi.org/10.1016/S0925-4005(03)00383-6

Widiyastuti, W., Setiawan, A., Winardi, S., Nurtono, T., Madhania, S., \& Susanti, D. (2012). The influence of Al dopant precursors on the characteristics of $\mathrm{ZnO}$ fine particles prepared by ultrasonic spray pyrolysis. Procedia Engineering, 50, 152-158.

\section{Copyrights}

Copyright for this article is retained by the author(s), with first publication rights granted to the journal.

This is an open-access article distributed under the terms and conditions of the Creative Commons Attribution license (http://creativecommons.org/licenses/by/3.0/). 